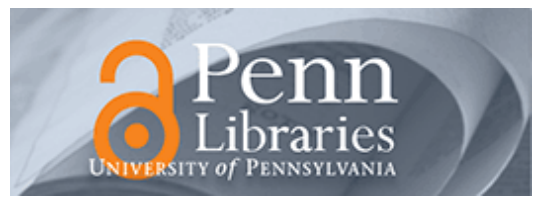

University of Pennsylvania

ScholarlyCommons

Finance Papers

Wharton Faculty Research

2007

\title{
Phoenix Rising: Legal Reforms and Changes in Valuations in Finland During the Economic Crisis
}

Timo Korkeamäki

Yrjo Koskinen

University of Pennsylvania

Tuomas Takalo

Follow this and additional works at: https://repository.upenn.edu/fnce_papers

Part of the Finance Commons, and the Finance and Financial Management Commons

\section{Recommended Citation}

Korkeamäki, T., Koskinen, Y., \& Takalo, T. (2007). Phoenix Rising: Legal Reforms and Changes in Valuations in Finland During the Economic Crisis. Journal of Financial Stability, 3 (1), 33-58.

http://dx.doi.org/10.1016/j.jfs.2007.02.002

At the time of publication, author Yrjo Koskinen was affiliated with Boston University School of Management and CEPR. Currently, he is a faculty member at the Wharton School at the University of Pennsylvania.

This paper is posted at ScholarlyCommons. https://repository.upenn.edu/fnce_papers/256

For more information, please contact repository@pobox.upenn.edu. 


\title{
Phoenix Rising: Legal Reforms and Changes in Valuations in Finland During the Economic Crisis
}

\begin{abstract}
Finland experienced an extremely severe economic depression in the early 1990s. As a part of the government's crisis management policies, significant new legislation was passed that increased supervisory powers of financial market regulators and reformed bankruptcy procedures significantly decreasing the protection of creditors. We show that the introduction of these new laws resulted in positive abnormal stock returns. The new laws also lead to increases in firms' Tobin's q, especially for more levered firms. In contrast to previous studies, our results also suggest that public supervision of financial markets fosters rather than hampers financial market development.

\section{Disciplines}

Finance | Finance and Financial Management

\section{Comments}

At the time of publication, author Yrjo Koskinen was affiliated with Boston University School of Management and CEPR. Currently, he is a faculty member at the Wharton School at the University of Pennsylvania.
\end{abstract}




\title{
Phoenix Rising:
}

\section{Legal Reforms and Changes in Valuations in Finland \\ during the Economic Crisis*}

\author{
Timo Korkeamäki \\ Gonzaga University \\ Yrjö Koskinen $^{+}$ \\ Boston University School of Management and CEPR \\ Tuomas Takalo \\ Bank of Finland
}

March 2007

\begin{abstract}
Finland experienced an extremely severe economic depression in the early 1990s. As a part of the government's crisis management policies, significant new legislation was passed that increased supervisory powers of financial market regulators and reformed bankruptcy procedures significantly decreasing the protection of creditors. We show that the introduction of these new laws resulted in positive abnormal stock returns. The new laws also lead to increases in firms' Tobin's q, especially for more levered firms. In contrast to previous studies, our results also suggest that public supervision of financial markets fosters rather than hampers financial market development.
\end{abstract}

\section{JEL Classification: G34, K22}

Keywords: corporate governance, bankruptcy, financial supervision, investor protection, corporate valuations, political economy, crisis management.

\footnotetext{
* We are grateful to Matthias Benz, Tom Berglund, Arturo Bris, Dan Friesner, Scott Harrington, Ari Hyytinen, Antti Kuusterä, Ted Moore, Andy Prevost, Andrei Shleifer, Joakim Westerholm and seminar participants at the Bank of Finland, Bocconi University, EPCS 2006 conference, Swedish School of Economics, University of Washington, FMA 2006 European conference, Boston University, FMA 2006 conference, and XV Tor Vergata Conference for helpful comments and Helinä Laakkonen for both excellent comments and research assistance. Comments from an anonymous referee and from Iftekhar Hasan (the editor) helped to improve the paper significantly. All remaining errors are our responsibility.

${ }^{+}$Corresponding author. Address: Boston University School of Management, 595 Commonwealth Avenue, Boston, MA 02215, USA. Phone: +1-617-353-9775. Fax: +1-617-353-6667. E-mail: yrjo@bu.edu.
} 


\section{Introduction}

Finland went through an economic depression in the early 1990s that was unprecedented in its severity for a highly developed modern economy ${ }^{1}$. An integral part of this depression was a banking crisis, where the government was forced to give massive bailouts to all the banks and to guarantee their contractual obligations. At the end of this crisis, one banking group was liquidated, two major banks and dozens of smaller banks were forced to merge. Finland's bank-dominated financial system was in ruins and had to be reformed.

Between 1991 and 1993, during the crisis, the government introduced new laws that resulted in transformation of the country's financial system. The change in securities law improved the integrity of the stock markets by establishing the new Financial Supervisory Authority with enhanced resources and regulatory powers. The other central piece of the legislation was a new bankruptcy procedure that made the reorganization of companies easier, mirroring the U.S. Chapter 11 process. To provide secured creditors an incentive to participate in reorganizations, their priority rights in liquidation bankruptcies were simultaneously weakened. Overall, the legal reforms improved the enforcement of shareholders' rights while weakening creditors' rights. By the end of 1990 s the financial system placed a more prominent role on the stock market as dependence on banks faded. ${ }^{2}$

The introduction of the new bankruptcy and securities laws provides us a unique opportunity to study how changes in creditor and shareholder protection affect corporate valuations. Typically, the relationship between investor protection laws and corporate valuations is studied using cross-sectional multi-country regressions (see for example La Porta, Lopez-de-Silanes, Shleifer, and Vishny, 2002). Those regressions are open to

\footnotetext{
${ }^{1}$ From 1990 to 1993 the GDP per capita declined by 14 percent and the unemployment shot up from 3 percent of labor force up to 20 percent (see Honkapohja and Koskela, 1999, for further details).

${ }^{2}$ See Hyytinen, Kuosa, and Takalo (2003) for further details.
} 
criticism of reverse causality: it is plausible that higher valuations lead to better investor protection laws. In addition, cross-sectional regressions can potentially lead to spurious findings due to numerous macroeconomic factors that are difficult to control for in the empirical design. We address these problems by employing the short-term event study method in addition to estimating panel regressions. Results obtained from short-term event studies are less likely to suffer from omitted macroeconomic variables potentially biasing results. The fact that our short-term event study and panel data estimation produce internally consistent results eases the concern about omitted variable bias in the latter ${ }^{3}$.

Since the law changes that we consider occur during a deep financial crisis, our study is also related to the emerging literature on crisis management policies. The basic insight arising from the recent literature (see e.g. Honohan and Klingebiel, 2003, Kane and Klingebiel, 2004, and Suarez and Sussman, 2007) is that the potential positive short-term effects of a soft approach towards banks and their borrowers are countered by detrimental long-term effects. However, in an influential contribution Shleifer and Vishny (1992) suggest that a bankruptcy law that stipulates an automatic liquidation upon default would have detrimental long-term macroeconomic effects, since during economic crises liquidated assets are likely to sell at a deep discount. Their results suggest that an introduction of reorganization into the bankruptcy code, as it happened in Finland, would reduce expected bankruptcy costs at the company level, and also that we should observe positive long-term effects on the macro level. Because stock prices are forward-looking, long-term effects can be expected to affect short-term stock returns, and particularly

\footnotetext{
${ }^{3}$ There is also a large literature that studies the relationship between firm-level corporate governance measures and stock returns or valuations. For example, Gompers, Ishii, and Metrick (2003) show that investing in better governed firms earns superior returns and that better governed firms trade at higher valuations. However, also papers that study the relationship between firm-level governance and valuations suffer from reverse causality: low valuations may lead to bad governance. Indeed, Lehn, Patro, and Zhao (2006) show that after controlling for prior valuations, there is no relationship between contemporaneous valuations and firm-level corporate governance.
} 
annual changes in corporate valuations. Thus our results may be relevant to this line of research as well.

We employ company level data from Worldscope, Helsinki Stock Exchange and Compustat spanning the years 1989 to 1993 . First, we utilize the event study method and examine whether the legal changes result in abnormal returns for a portfolio of Finnish companies. We do not detect a market reaction when the newspapers first report that the government is considering new securities or bankruptcy laws. Most likely, information about potential law changes had leaked to the market participants before the first newspaper report about them appeared. ${ }^{4}$ However, we find a positive stock market reaction when the bills are first introduced to the parliament. This result applies to both improved enforcement of shareholders' rights (establishment of the new Financial Supervisory Authority) and weakening of creditors' rights (the new bankruptcy rules). Our results regarding creditor right changes could in principle imply either a wealth transfer from creditors to shareholders, or alternatively a net positive wealth creation. We find support for the wealth creation hypothesis by showing that also financial institutions - by far the most important creditors in Finland during the time of the reforms - experienced a positive stock market reaction. In contrast to Barth et al. $(2004, \underline{2006})$ and La Porta et al. (2006) we find evidence that public enforcement of securities laws also matters, as the creation of the Supervisory Authority is met by a positive stock reaction.

There is no market reaction when the parliament passes the laws. When the government introduces the legislation to the parliament the laws are fundamentally in their final forms, thus resulting in significant market reactions. Since Finland had a strong majority government at the time of the reforms, the final passing of the laws was just a mere formality with no new informational content.

\footnotetext{
${ }^{4}$ The muted reaction is also in line with previous event studies on the effects of law changes such as Binder (1985), which point out the difficulties in specifying the appropriate first event date.
} 
In seeking the determinants of the abnormal returns, we find that levered firms experience more positive abnormal returns when laws that weaken creditors' rights are introduced to the parliament. This result suggests that stockholders of more levered firms reap greater benefits from the new, more lenient bankruptcy procedures. Lastly, we study the effects of the four legal reforms considered on Tobin's q. Our panel regression results confirm that more levered firms experience higher valuations as a result of the legal reforms.

Besides supporting the connection between law and finance, we also contribute to the recent political economy literature that considers motivations behind legal reforms (Pagano and Volpin, 2005, 2006, Perotti and von Thadden, 2006). It can be argued that the far reaching corporate governance reforms in Finland were made possible by the deep crisis that caused labor to lose its rents ${ }^{5}$. This reduced labor's incentive (and ability) to resist reforms. The reforms were passed under a right-wing government that did not include - for the first time in 25 years - left-wing parties closely associated with labor unions.

Besides labor unions, the banks had traditionally been an influential interest group in Finland. The worsening of creditor rights was thought to run against their interests. However, the banking crisis and subsequent reorganization of the banking sector meant a deterioration of banks' previously strong industrial and political power. For example, the Act on Reorganization of Companies was adopted despite protests by the Finnish Bankers' Association and the Finnish Brokers' Association (whose objection to the Act is documented in Government bill 182/1992). In sum, the financial crisis in Finland significantly worsened the bargaining power of two powerful interest groups, labor and banking sector, which seemed to open the door for more shareholder friendly legislation.

\footnotetext{
${ }^{5}$ This loss is manifested by the above-mentioned change in unemployment, from 3\% in 1990 to $20 \%$ in 1993 (cf. footnote 1).
} 
The paper is organized as follows: Section two reviews the legal changes in Finland that occurred during the crisis years and their role in the government's crisis management. Section three provides a discussion of the connections among investor protection, stock valuations, and macroeconomy. Section four presents the data and Section five the results. Section six discusses the political economy implications, and Section seven concludes.

\section{Changes in investor protection in Finland}

\subsection{Legal and institutional background before the reforms of $1991-93$}

Finland was highly advanced in terms of overall legal development at the start of the 1980s. As Demirgüç-Kunt and Maksimovic (1998) report, the International Country Risk Guide gave Finland the highest possible score for the years preceding the economic crisis, 1985-1991, in its law and order index, which measures reliance on the legal system in mediating disputes and enforcing contracts. The IMD's World Competitiveness Yearbook placed Finland fourth in 1990 on fair administration of justice (IMD, 1990). The level of the legal system has remained excellent also after the economic crisis. Finland is ranked fifth in the IMD yearbook of 2005 for the state of the general legal and regulatory framework. ${ }^{6}$ The World Economic Foundation's Global Competitiveness Report 20042005 generally echoes these results, placing Finland first in the general growth competitiveness index and emphasizing judicial independence and property rights as

\footnotetext{
${ }^{6}$ Regarding the fair administration of justice, Finland's score in the 1990 World Competitiveness Yearbook is 84.17 (of 100) and in the 2005 Yearbook 8.75 (of 10). Finland's score regarding the state of the legal and regulator framework in the 2005 Yearbook is 6.82 (of 10).
} 
major sources of competitive advantage (Porter, Schwab, Sala-i-Martin, and Lopez-Claros, 2004).

Although the foundations of the legal system were solid, Hyytinen et al. (2003) document that Finnish legislation concerning minority shareholder protection, based on The Companies Act of 1978, was underdeveloped in the 1980s. The creditor rights, while generally strong, were founded on the Liquidation Bankruptcy Code and the associated Decree on Claim Priorities dating back to 1868, and the Act on Compositions of 1932. Only minor changes to the laws were enacted before the reforms of the early 1990 considered in this study. As a result, until 1993, the principal route of resolution of financial distress was liquidation bankruptcy. When a firm was declared bankrupt, a trustee took over the firm and sold its assets. The firm could either have been sold as a going-concern or liquidated piecemeal. The proceeds were then distributed to creditors according to priority of claims. Workouts, or compositions established by a court, provided in principle an alternative way of resolution until 1993. However, they were rarely used, as documented in Government bill 182/1992.

The principal supervisory authority for banking and financial markets was the Banking Supervision Office, established under the Ministry of Finance in 1922. The Banking Supervision first only dealt with commercial banks, but its tasks were gradually expanded in the 1970s and 1980s so that virtually all banks and securities market institutions were brought under its supervision by the late 1980s. Besides the Banking Supervision Office, the Bank of Finland also had a duty to oversee financial institutions. In particular, the Bank of Finland was assigned the role of supervising the currency risks of financial institutions. In addition, the central bank had a general interest in maintaining financial stability due to its role as the lender of last resort. 
During the early 1990s, the government implemented a number of reforms of the Finnish economic and financial system. We focus on the changes in investor protection legislation that can be captured by indexes developed by La Porta et al. (1997, 1998), Pistor (2000), and Pistor, Raiser and Gelfer (2000) ${ }^{7}$.

Three pieces of legislation affecting creditor rights were passed in 1991 and 1992: the Act on Restitution of Assets in Bankruptcy 758/1991 (effective January 1, 1992), the Act on Claim Priorities 1578/1992 (effective January 1, 1993), and the Act on Reorganization of Companies 47/1993 (effective February 8, 1993). The Act on Restitution of Assets in Bankruptcy extended the time limits when pre-bankruptcy transactions could be revoked. The Act on Reorganization of Companies introduced court supervised reorganization for financially distressed firms. As Ravid and Sundgren (1998) demonstrate, it is similar to the US Chapter 11 bankruptcy procedure. It was accompanied by the Act on Claim Priorities that promoted more equal treatment of creditors in liquidation bankruptcy and simplified creditor priority rules.

The Act on the Financial Supervisory Authority 503/1993 (effective June 11, 1993) significantly increased the resources and the regulatory powers of financial supervision. In addition, it unified the dispersed banking supervision to one organization, which operates in connection with the Bank of Finland. The responsibility of monitoring the currency risks of banks was transferred to the new Authority, but the Bank of Finland maintained a general interest in the banking sector stability due to its role as the lender of the last resort.

These reforms altered La Porta et al.'s and Pistor et al.'s index values as follows:

\footnotetext{
${ }^{7}$ The quantification of the legal changes in Finland is taken from Hyytinen et al. (2003). We also carefully checked out their codifications. See the Appendix for a more detailed discussion.
} 
- The Act on Restitution of Assets in Bankruptcy of 1991 improved creditors' rights, as measured by an increase in Pistor et al.'s index for creditors' legal possibilities to punish management (REMEDY) index from 1.5 to 2 ( $\max 3)$.

- The Act on Financial Supervisory Authority of 1993 improved shareholder protection, as measured by an increase in the value of Pistor et al.'s stock market integrity index (SMINTEGR) from 5 to 6 (max 6).

- The Act on Reorganization of Companies of 1993 weakened creditors' rights, as measured by a decrease in La Porta et al.'s creditor right index from 4 to 1 (max 4), the extended La Porta et al.'s creditor right index from 4 to 1 (max $5)^{8}$, and Pistor et al.'s index for creditors' control of the bankruptcy (CREDCON) from 3 to 1 ( $\max 5)$.

As the indices suggest, the Act on Reorganization of Companies in 1993 was detrimental for creditor protection. The reform weakened the restrictions on going into reorganization and expanded the scope of the automatic stay on assets. It also diluted creditor rights by enabling management to remain in charge during the reorganization. Since a purpose of Pistor et al.'s CREDCON is to create a La Porta et al. - type creditor right index that is useful in circumstances where legislation does not recognize the US style reorganization, it provides a robustness check for our coding. Because this index value also drops, we can be more confident that the Act on Reorganization of Companies drastically weakened creditor protection.

Although the Act on Claim Priorities did not affect the index values, we have included it into our analysis, since it was integral to the Act on Reorganization of Companies: these two laws were planned and introduced to the Parliament in a package. Like the Act on

\footnotetext{
${ }^{8}$ The extended La Porta et al.'s creditor right index was initiated by Pistor (2000) and Pistor et al. (2000). This index adds to La Porta et al.'s creditor right index a discrete variable for the provision for a legal reserve, i.e., the minimum percentage of total shares required to avoid dissolution of the company. This variable appears originally also in La Porta et al. $(1997,1998)$ but is not a part of their index.
} 
Reorganization of Companies, the Act on Claim Priorities represented a major reform of creditor protection which reduced the rights of secured creditors (Bergström, Eisenberg, and Sundgren, 2004). In particular, creditors holding a floating charge ${ }^{9}$ had priority in 100 percent of their collateral before the reform, but only in 60 percent after it.

As a result of the deterioration of creditor rights, Finnish legislation currently provides a lower level of creditor protection than most common or civil law countries, as reported in La Porta et al. $(1997,1998)$. The score of 1 for Finland in 2000 is lower than the world average of 2.3 and the Nordic average of 2.0. Prior to 1993, the score for Finland was 4. The comparisons to La Porta et al. results should, however, be interpreted cautiously, because the legislation may also have been changed in other countries.

Other creditor rights measures have remained strong or even improved. Measured by Pistor et al.'s index for collateral rules (COLLAT), Finnish legislation continues to provide a maximum level of investor protection. Due to the passing of the Act on Restitution of Assets in Bankruptcy in 1991, it has become easier to nullify transactions that preceded the initiation of bankruptcy proceedings. The Act increased possibilities to punish the management (as measured by Pistor et al.'s REMEDY-index).

\subsection{The role of the legal reforms in crisis management}

The legal reforms we study were a part of the Finnish government's extensive policy response to the economic crisis. ${ }^{10}$ Preceding the crisis, the financial market deregulation of the 1980s had intensified competition between financial institutions and launched rapid lending growth. When borrowers' incomes and wealth declined dramatically in 1991 and

\footnotetext{
${ }^{9}$ A floating charge is a non-possessory claim against a debtor's current assets.

10 The Finnish economic crisis and the government's macroeconomic policy response are described and analyzed in the special issue of the Finnish Economic Papers (e.g. Corsetti and Roubini, 1996, and Jonung, Söderström, and Stymne, 1996) and in Honkapohja and Koskela (1999).
} 
bankruptcies soared, the banks started to experience severe problems. ${ }^{11}$ The currency crisis further weakened the borrowers' debt service capacities, especially because many had borrowed in foreign currencies without corresponding foreign incomes. Vihriälä (1997) reports that confidence in the Finnish economy and financial system deteriorated in winter 1992-93 to the extent that the Finnish banks and large corporations encountered severe difficulties in borrowing from abroad.

\section{Table 1 here}

To prevent the banking sector from collapsing and to limit the adverse impact of the financial sector problems on the real economy, the government intervened. The intervention is carefully documented in Nyberg and Vihriälä (1994). As in many other countries, the government's actions towards troubled banks were generally "accommodating", including extensive liquidity support and blanket guarantees. ${ }^{12}$ However, Nyberg and Vihriälä (1994) also classify the reorganization of the banking and financial market supervision among the major components of the intervention. Governmental documents, e.g. the Financial Supervisory Working Group's Report for the Ministry of Finance and Government bill 319/1992, clearly indicate that the failure to detect the banking crisis was primarily due to the lack of supervisory resources and inadequate cooperation between various supervisory authorities. This raised the concern that the prevailing supervisory structure could not cope with the ongoing banking crisis. Accordingly, the reform pooled the scattered banking and financial market supervision into a single, independent entity that begin to operate in connection with the central bank.

\footnotetext{
${ }^{11}$ See e.g. Figure 5 in Sorge and Virolainen (2006) for the development of bankruptcy volume in Finland 1986-2003. Their study shows how the Finnish economic and the associated banking crisis provide an outstanding background for evaluating existing macro stress-testing methods.

12 See Honohan and Klingebiel (2003) and Kane and Klingebiel (2004) for surveys of crisis management policies employed in banking crises around the world.
} 
The resources devoted to supervision were increased significantly. The idea was that the concentration of supervisory activities and closer cooperation with the central bank should improve communication and eliminate overlapping regulatory efforts. In addition, it was hoped that the new, independent supervisory authority with bigger resources would help to restore the confidence to the Finnish financial markets.

In contrast, it seems that the government's main objective in the creditor rights reform was to help the distressed real sector rather than banks. The Ministry of Justice had set up a working group to prepare a thorough reform of bankruptcy legislation already in January 1990, but the rocketing number of bankruptcies rendered the reform urgent. The working group was given less than ten months to complete the task, which was focused on the reform of the old Decree on Claim Priorities of 1868 and the introduction of a new legislation enabling effective reorganizations. These reforms were deemed to be more critical than other planned changes in bankruptcy legislation.

Amidst the crisis it was felt that illiquid but solvent companies were unnecessarily liquidated because of strong position of secured creditors under the old bankruptcy regime. Secured creditors were well protected in liquidation bankruptcy and had virtually no incentive to voluntarily participate in debt restructuring in workouts under the Act of Compositions of 1932 (see the Appendix). In practice, debt restructuring was possible only under unanimous consent by secured creditors and were plagued by collective action problems. This raised the need for implementing a reorganization procedure in which any single creditor could no longer hold up debt restructuring. To guarantee that secured creditors would have an incentive to participate cooperatively in reorganizations, their rights in liquidation bankruptcies had to be weakened correspondingly. However, it was recognized that lowering the strong priority rights of secured creditors in liquidation bankruptcies could jeopardize the supply of debt funding. The policy makers tried to 
balance these opposing goals by maintaining the general high priority ranking of secured creditors, but also capping the maximal amount they could recover in liquidations.

\section{The economic impact of legal reforms}

\subsection{Corporate valuations}

The effect of the decrease in creditor protection due to the bankruptcy reform on corporate valuations is ambiguous a priori. The Finnish government's objective in introducing the alternative bankruptcy procedure (as stated in Government bill 182/1992) was to make reorganizing distressed companies easier and thus to avoid liquidation of illiquid, but economically viable companies. Any reduction in dead-weight bankruptcy costs should lead to increased share values. Similarly, a wealth transfer from creditors to shareholders would cause a positive stock price reaction. Accordingly, our observed stock prices should react positively to three law changes out of the four that we study, since two of them represent a decrease in creditor rights and one is an increase in shareholder protection. The Act on Restitution of Assets in Bankruptcy of 1991 marks an improvement in creditor rights, so the stock price reaction to that law should be opposite to the reactions to the creditor right reductions. As our sample period includes two law changes that brought significant reductions in creditor rights, one that slightly improved creditor rights, and one that improved shareholder protection, we would expect that Tobin's q increases in the panel data estimations using annual data, especially for more levered firms.

However, improving the ex-post efficiency of bankruptcy procedures could lead to negative ex-ante effects: credit could become harder to get or its price could increase (see e.g. Bolton and Scharfstein, 1996; Cornelli and Felli, 1997). Thus a drastic weakening of creditor rights might constrain firms financially and therefore affect the value of common stock negatively. Consistent with this argument, Scott and Smith (1986) document a 
contraction in credit availability for U.S. small firms following the Bankruptcy Reform Act of 1978. The changes caused by this U.S. legislation to small businesses in many ways resemble the Finnish bankruptcy law changes considered in the current study. Resultant credit constraints would imply a negative stock price reaction to the two dilutions of creditor rights, and a positive reaction to the one creditor right improvement.

Besides uncertainty about the direction of the stock reaction upon bankruptcy law changes, ambiguity applies to the effects of the creation of the Financial Supervisory Authority as well. It is widely thought that stronger supervisory powers of financial market regulators nurture financial market development. This notion underlies the second pillar of the Basel II financial market regulations. However, this idea has received very sparse empirical support. Recent findings rather indicate that strengthening public supervision is at best irrelevant for financial market development (Barth, Caprio, and Levine, 2004, 2006; La Porta, Lopez-de-Silanes, and Shleifer, 2006). It is even possible that the creation of the Financial Supervisory Authority further constrains financing by placing additional bureaucratic burdens on banks thus resulting in negative stock price reactions. In addition, stock values could also suffer if the demand for equity by controlling shareholders is reduced due to diminished access to control benefits (see Giannetti and Koskinen, 2007).

The above discussion implies that weakening of creditor rights and the creation of the Financial Supervisory Authority can also have opposite effects on financial market development: the former having a positive and the latter a negative effect or vice versa.

\subsection{Macroeconomic effects}

The recent literature on the management of banking crises has cast a doubt to the efficiency of an accommodating approach that has been popular in various countries (see e.g. Honohan and Kilngebiel, 2003, and Kane and Klingebiel, 2004). Although the Finnish 
government also used such a soft approach and provided extensive liquidity support and blanket guarantees to troubled banks, the legal reforms we study cannot only be labeled as creditor-friendly. In particular, the establishment of the new Financial Services Authority could be interpreted to be a form of a strict crisis management approach that emphasizes the need to follow the rules.

A related literature seeks to understand the macroeconomic effects of bankruptcy laws. Shleifer and Vishny (1992) are the first to formally consider the general equilibrium implications of bankruptcy law. Their findings complement earlier suggestions by Easterbrook (1990), that a possibility to renegotiate contracts upon default should be value-enhancing. Since the causes of corporate financial distress is often not limited to individual companies, but are rather related to industry- or economy-wide economic downturns, a liquidation bankruptcy is likely to result in asset sales at the worst possible time. At the firm level, fire sales result in large value losses. At the macro level disruption in operations, caused by liquidations, only further hurt the already ailing economy. According to Shleifer and Vishny (1992), the ultimate result is deepening of the crisis. This view is challenged by Suarez and Sussman (2007). Their model implies that softening of bankruptcy law fails to produce the desired effect of increased long-term financial stability. They suggest that lenders will react to the softer bankruptcy law by constraining credit, which will eventually cause greater financial instability. The findings discussed above by $\underline{\text { Scott and Smith (1986) }}$ support this notion, as U.S. small businesses faced a constrained credit market following the Bankruptcy Reform Act of 1978.

\section{Data description}

We utilize two different main data sources. Our Finnish stock return data were obtained directly from the Helsinki Stock Exchange. That data set contains the entire 
universe of Finnish publicly traded firms. The accounting data that we use in the cross sectional analysis comes from Worldscope. Since the Worldscope coverage is limited compared to our returns data, our sample size varies depending on which tests we perform. However, our return results are robust to exclusion of firms that are not part of the Worldscope sample.

Table 2 provides some descriptive statistics for our Worldscope sample across the five years (1989-1993) included in this study. Panel A contains the entire sample, and Panel B includes only firms that are present in all five sample years. Notably, the medians of revenues and assets in Panel A have significantly decreased during our sample, as smaller companies have entered the Worldscope dataset each year. According to both Panels A and B, following the drastic reduction in creditor protection leverage (calculated as long-term debt divided by total assets) dropped significantly from 1992 to 1993. Panel $\mathrm{C}$ indicates that our sample is dominated by manufacturing and financial sectors.

\section{Table 2 here}

We also report the median Tobin's q values for our sample in Table 2. We calculate Tobin's q according to equation (1). If the reductions in creditor protection result in wealth transfers from creditors to stockholders, we would expect to observe economy-wide increases in Tobin's q. As Panel B of Table 2 shows, we detect an improvement of almost 19\% in Tobin's q between 1992 and 1993 for firms in our balanced panel. In fairness, it should be noted that the result for 1993 indicates a return in Tobin's q values to the precrisis levels of 1989. The lack of improvements in Tobin's q over the entire sample horizon could be explained by the severity of the economic crisis.

Tobin's q $=$ (total assets - bv common stock + market capitalization $) /$ total assets 


\section{$5 \quad$ Results}

\subsection{Event study results}

We begin a more rigorous analysis by conducting an event study around events related to the four law changes that we study. For each law change, we identify three dates of interest - (1) the first announcement date identifying the first mention of each law in Kauppalehti, the leading Finnish daily business newspaper, (2) the date when each law change was introduced by the government to the parliament, and (3) the date when the law was enacted by the parliament ${ }^{13}$.

As documented in Hyytinen et al. (2003) the Finnish stock market was relatively small in size and liquidity in the early 1990s. Our event window of $(-2,+1)$ should allow time for any new information to be assessed. Also, by including two trading days prior to the public announcement, we hope to capture information leakages prior to the events. Potential for such leakages exists in markets where information amongst market participants may be superior to that observable by the general public (or a researcher).

Common with prior research into law changes, such as Binder (1985), and several others, we have an extreme case of event date clustering amongst our sample firms, which is likely to cause the abnormal returns to be correlated in the cross-section. Therefore, we are unable to test for significance using the "traditional" event study methodology as outlined by Brown and Warner (1985). When the entire sample shares the event date, Schwert (1981) and Campbell, Lo, and MacKinlay (1997) suggest aggregating individual stock returns into a portfolio and analyzing abnormal returns of that portfolio. We follow their suggestion and compile an equally-weighted portfolio of all stock returns available

\footnotetext{
${ }^{13}$ Since a law proposal in Finland can, even under strong majority governments, be subject to changes after the proposal has been introduced to the Parliament, we also considered several other events related to each law, such as the steps that the law proposals took through the parliament committees. Those events did not
} 
around each of our events ${ }^{14}$. This "portfolio method" is also used by Ali and Kallapur (2001), Karpoff and Malatesta (1989) and others. The abnormal returns for our portfolio are measured by the coefficient $\beta_{2}$ in equation (2) ${ }^{15}$.

$$
R_{p f, t}=\alpha+\beta_{1} R_{m k t, t}+\beta_{2} D_{(-2,+1)}+\varepsilon
$$

where

$R_{p f}=$ Return on the equally-weighted Finnish stock portfolio on day $t$;

$R_{m k t}=$ Return on the MSCI World index on day t;

$D_{(-2,+1)}=$ Dummy variable that takes on value of one during the event window, zero otherwise.

For each event, we use trading days $(-250,-10)$ as the estimation period. In other words, we include $(-250,-10)$ in each estimation, while excluding the days leading into each event $(-9,-3)$. For the market portfolio $\left(R_{m k t}\right)$, we use the MSCI World index. Our findings are essentially identical if we use alternative European indices instead.

\section{Table 3 here}

The abnormal portfolio returns are presented in Table 3 . We report the $\beta_{2}$ coefficient and the t-statistic for each event. If reductions in creditor protection and increases in shareholder protection are positive news to the stock market, the stock prices should react positively to three out of the four law changes that we consider, since two of the four law changes represent a reduction in creditor rights and one represents an improvement in shareholder protection. The Act on Restitution of Assets in Bankruptcy of 1991 represents an improvement in creditor rights. Thus, the stock price to reaction to that law should be

convey new information to the market, evidenced by insignificant event study results. Also, the press coverage of each law after the first announcement was largely inconsequential, judged by abnormal returns.

${ }^{14}$ Using equal weights in Finland would be problematic for more recent years due to the relative size of Nokia. However, in our 1989 sample Nokia has only third largest market capitalization. 
opposite of the reaction to The Act on Claim Priorities of 1993 and The Act on Reorganization of Companies of 1993.

Only one of the first announcements is met by a statistically significant stock reaction. Namely, the reaction to the first announcement of The Act of Financial Supervisory Authority of 1993 is positive and significant at the 1\% level. Lack of reaction to the other first announcements can be explained either by the events having no effect to the stock returns, or by the difficulty in observing the true event date. In Finland's corporatist economy, drafts of laws are subjected to a consultation process before they are introduced to the Parliament. It is therefore likely that information about potential law changes had leaked to investors before the first newspaper report about them appeared. Also, it is possible that these first announcements were so vague that no news of economic significance was conveyed by them.

However, introduction to the parliament is an event that is accompanied by a positive and significant reaction in all of the three cases where we expect a positive reaction. The date when the law is introduced to the parliament is the first date when a full version of the law is available to the public. While this is only the first introduction of the law, we emphasize that during our sample period, the parties in the Finnish government held a solid majority of the seats in the parliament, and therefore the eventual final version of the law was likely to be almost identical to the one that was originally introduced. ${ }^{16}$ The Act on Reorganization and the Act on Claim Priorities were both introduced to the parliament on September 25, 1992, and that event produces the most significant market reaction, with the t-statistic of 3.81. Recall that both of those laws reduced creditor rights, and that the Act on Reorganization alone lead to a change in the LLSV creditor right index from 4 to 1 . The fact that The Act on Financial Supervisory is met by a positive stock

\footnotetext{
${ }^{15}$ Using the MVRM method as outlined by Binder (1985) gives quantitatively similar results.
} 
reaction both at the first announcement stage and at the introduction to the parliament stage is interesting. As mentioned above, previous multinational studies have failed to detect positive value in financial supervision. Therefore, the current study is the first one that we are aware of reporting a positive effect from an increase in financial supervision. Finally, the introduction of The Act on Restitution of Assets did not result in an abnormal stock reaction.

Given the strong majority government, the date when the law is enacted by the parliament is likely to be of limited importance in terms of conveyance of new information. Indeed, only one of the four enactment events is met by a significant reaction. Namely, the reaction to the Act on the Financial Supervisory Authority exhibits a negative sign. This is a surprising finding, given the positive reaction to the other two events related to this law change. The parliamentary committee responsible for reviewing the Act wanted to emphasize the independence of the Financial Supervisory Authority from the Bank of Finland. We deem the resulting changes in the Act to be minor, but the market may have interpreted the modification differently. Perhaps the market thought that more independent Financial Supervisory Authority weakened the Bank of Finland's commitment to be the lender of the last resort.

Next, we analyze the cross-sectional determinants of individual cumulative abnormal returns around each event in Table 4. We estimate firm-specific cumulative abnormal returns, again using the estimation period of $(-250,-10)$, and the event window of $(-2,+1)$. We continue to use the MSCI World Index as the market portfolio ${ }^{17}$. Each column of Table 4 represents one of the four law changes. The dependent variable in each column is the cumulative abnormal return (CAR). All three events related to each law; the first announcement, the introduction to the parliament, and the final enactment of the law, are

\footnotetext{
${ }^{16}$ The laws we study were modified by the Parliament, but according to our reading of the modifications, they were minor and concerned more technical details. Our event study evidence confirms our judgment (cf. footnote 13).
} 
included in the sample for each column. In testing whether the marginal effect of leverage around a law-change event affects the stock reaction to that event, our test variables are the interaction variables between leverage and the event dummy. In each specification, we control for whether the firm is a financial institution, and for the firm's leverage, marketto-book, size (measured as log of assets), and dividend payout ratio. The financial institution dummy is intended to represent not only the difference in the balance sheet structure between financial and non-financial firms, but also the special role that financial institutions play as creditors. Market-to-book ratio is set to control for potentially different reaction in industries with higher market multiples. The size variable controls for any difference in small vs. large firm stock reactions. Finally, the dividend payout ratio proxies the financial constraints of the firm, in the spirit of Fazzari, Hubbard, and Petersen (1988). All firm-specific variables are observed in the year-end preceding the event date.

Table 4 here

Reductions in creditor rights should be more beneficial for firms with high leverage. Thus, we expect the coefficient for the interaction terms between leverage and the event indicators to be positive for the Act on Reorganization of Companies of 1993 (Reorg 1993), and the Act on Claim Priorities of 1993 (Claim Priorities 1993). Following the same logic, the marginal effect of leverage on market reaction to the Act on Restitution of Assets in Bankruptcy of 1991 (Bankruptcy 1991) should be negative. It is unclear whether the amount of debt would affect the stock reaction upon an improvement in shareholder rights, and therefore the expected sign of the interaction terms in conjunction of The Act on Financial Supervisory Authority of 1993 (Supervisory Auth. 1993) is more ambiguous.

\footnotetext{
${ }^{17}$ The use of alternative market portfolios leaves our findings intact.
} 
While leverage does not appear to affect the stock reactions to the other three law changes, the reactions to both the first announcement and the introduction to the parliament of the Act on Claim Priorities of 1993 are significantly affected by leverage. The positive stock reaction to this regulation, reported earlier, seems to be driven by levered firms.

\subsection{Panel regression results}

Another way to observe the effect of creditor protection on the stock values is to measure changes in Tobin's q during the period of law changes. In Table 5, we report results from panel data estimation, where we have used measures related to Tobin's q as dependent variables. While Table 2 gave some evidence of increases in the Finnish stock values in 1989-1993, firm-specific variables might shed more light to the factors behind changes for individual companies.

Table 5 here

In the first two columns of Table 5, we report the panel regression results when the natural log of Tobin's $q$ is used as the dependent variable. We control for leverage, firm size (Log of total assets), and also for macro effects that took place in years 1991, 1992, and 1993 (dummy variables for each year, respectively) on Tobin's q. However, our main interest is in the interaction variables Year $91 \times$ leverage, Year $92 \times$ leverage, and Year 93 $\mathrm{x}$ leverage. These variables should capture the marginal effect of higher leverage on Tobin's q in each of the three years. As with the tests above regarding the short-term reactions to the law changes, we expect that the effects of law changes that "hurt" 
creditors should be more positive for companies with more debt. Therefore, we expect the sign on the interaction variables to be positive.

We report both firm-level fixed effects and random effects results. In the first panel regression, Hausman test fails to reject the random effects model, and therefore we should focus on the results in column 2. The results in column 2 suggest a strong positive connection between Tobin's q and leverage in years 1991 and 1992. Both coefficients are statistically significant at the $1 \%$ level or better. These results support either the wealth transfer view, or the alternative view that loosening of creditor protection enhances financial market development. The latter possibility could be viewed as support of Shleifer and Vishny (1992), as the law changes seem to coincide with the point amid the economic crisis when the Finnish economy begins to accelerate. ${ }^{18}$

In the last two columns of Table 5, we control for industry-specific changes in stock values. We obtain U.S. data within each company's two-digit SIC code from Compustat, and calculate the U.S. industry median for each Finnish firm. The U.S. makes a good point of comparison as creditor protection remained unchanged in the U.S. during the period of interest. The dependent variable in our last panel regression is the difference between the sample firm's Tobin's q and its U.S. industry median. The Hausman test indicates that we should this time focus on the fixed effects model. Each of the interaction terms from 1991 to 1993 are positive, with year 1992 exhibiting the most significant growth. This provides further backing for the connection between leverage and value changes.

\subsection{Robustness Checks}

\footnotetext{
${ }^{18}$ Recall that at the macro level, sustained benefits of relaxation of bankruptcy law have been questioned. While our results support Shleifer and Vishny (1992), they are not necessarily in conflict with Suarez and Sussman (2007) either. First, our tests may not fully capture the long term effects of the changes. Second, the alternative policy tools suggested by Suarez and Sussman, namely bailouts and monetary policy, were also actively used in Finland during our sample period.
} 
As mentioned above, empirical studies of this nature suffer from the suspicion that findings are ultimately driven by some other macroeconomic variables that have not been considered in the empirical design. The fact that Finland was living through a very deep economic crisis during our sample period heightens such suspicion.

Finnish banking sector went through a major crisis during the early 1990s. While a low number of banks in our sample limits the concern, these bank stocks could be biasing our results. In our cross-sectional analysis in Table 4, we utilize a dummy variable for financial institutions to control for any extraordinary effects caused by such institutions. Also, our event study results reported in Table 3 are robust to exclusion of financial institutions, which is shown in the first column of Table 6. Each event that was statistically significant in Table 3, receives the same sign at the same level of statistical significance when financial institutions are left out of the portfolio.

Table 6 here

As mentioned above, the stock value increases reported above could be explained by a wealth transfer from creditors to shareholders, rather than by value creation. To explore this proposition, we rerun the event study tests of Table 3 with a portfolio that contains only financial institutions. These results are reported in the center column of Table 6 . If the overall value gain is explained by a wealth transfer, we should expect financial institutions - the predominant creditors in Finland at the time - to experience a value reduction upon the law-changing events. However, the financial institution portfolio results are very similar to those reported in Table 3, with t-statistics of 4.1977 for the September 25, 1992 event, suggesting wealth creation rather than wealth transfer as a 
cause of our results ${ }^{19}$. Our result of value creation is also consistent with the results in Sundgren (1998), who shows that after the Finnish bankruptcy reform creditors were able to receive higher payoffs in reorganizations compared to liquidations.

Amid the economic crisis in Finland, the European Monetary System experienced tumultuous times in 1992, and Finland played a significant role in those developments. Speculative attacks on the Finnish Markka caused the Bank of Finland to float the currency on September 8, $1992^{20}$. Since the decision to float Markka resulted in an immediate devaluation of the currency by about $15 \%$, the stock reaction to the currency regime change might vary depending on whether the firm is involved in export trade or not. Therefore, we define a dummy variable NONEXP, which takes on value of one for firms that are in the service sector or in domestic retail or wholesale trade.

In the right-most column of Table 6 , we rerun the portfolio method test in Table 3 with a portfolio that includes only the NONEXP firms. The results regarding September 25, 1992 law change event remain significant, with the t-statistic of 2.165. As mentioned earlier, same is true for the findings reported in Table 4. When only the September 25, 1992 event is included in the cross-sectional analysis, the t-statistic for LEVERAGE is 1.954, even though the sample size is smaller when the export firms are excluded (results not reported).

Annual data used in our panel estimation is more likely to reflect effects of the currency regime change. Therefore, we re-estimate the models in Table 5 with additional interaction variables added, and the results are reported in Table 7. The added variables, YEAR $91 \times$ NONEXP, YEAR $92 \times$ NONEXP, and YEAR 93 x NONEXP enter with

\footnotetext{
${ }^{19}$ Interestingly, the stock prices of financial institutions do not react positively to the Act on Financial Supervisory Authority, like other companies do. Perhaps the reason for this finding is that financial institutions were already very closely monitored since the beginning of the banking crisis.

${ }^{20}$ Some minor changes in the wording of this currency regime change were even introduced to the parliament on September 25, 1992 - the same day when two of the four law changes studied in this paper were also introduced to the parliament. The prevailing law allowed the Bank of Finland to float the currency
} 
negative signs, the findings regarding years 1992 and 1993 being statistically significant. This suggests that stock values in non-export sectors suffered from the currency regime change, as expected. However, when Table 7 results are compared to those reported in Table 5, very little change can be detected regarding the effect of leverage on value change.

Another significant change in the Finnish financial market regulation during our study period was the removal of the restrictions on the foreign investment in the Finnish stock market in 1993. While we do not have data on foreign ownership of our sample companies, we attempt to control for the effect of the liberation of foreign ownership with an additional set of interaction variables between the year dummy variables and total assets. This is based on an assertion that larger firms are likely to attract more foreign investors (as documented by Kang and Stulz, 1997, for example). Adding these additional interaction variables to the specifications reported in Table 6 leaves our findings intact, while the coefficients on the added interaction variables are weakly positive (results not reported).

\author{
Table 7 here
}

\title{
6 Political economy of the reforms
}

Current level of financial development is not permanent, as shown by Rajan and Zingales (2003, 2004). Finland is an excellent example of this. Rajan and Zingales argue that financial markets will develop only when a country's political structure changes or incumbents allow development to take place. The Finnish case also illustrates the benefits of legal reform of corporate governance and its obstacles arising from interest group 
politics as emphasized by La Porta et al. (2000). The subsequent literature of political economy and corporate governance tries to further isolate the reasons of why and how investor protection laws and financial development evolve as a result of political process. In Pagano and Volpin (2005, 2006), workers align themselves with existing owners against outside financiers when workers do not participate in stock markets, resulting in low level of investor protection and high level of employment protection. Similarly, Perotti and von Thadden (2006) show that median voters are likely to support conservative bank-dominated financial system when they do not own stocks, but switch to supporting more risky market-based financial system when they become owners.

The mechanism for major reforms in Finland can be seen as the opposite of that in Pagano and Volpin $(2005,2006)$ and Perotti and von Thadden (2006), which would both predict that major reforms occur after workers or median voters have increased their stock ownership. In Finland, the reforms were preceded by workers' rents first dissipating through higher unemployment. After that legal reforms became possible as workers had nothing to lose and perhaps something to gain in the future from improved shareholder protection laws.

The developments in Finland during the early 1990s fit better the crisis-inducedreform hypothesis (see, e.g. chapter 10 in Drazen, 2000, and Drazen and Easterly, 2001). The traditional version of the hypothesis maintains that a sufficiently severe economywide crisis launches macroeconomic policy reforms. A related argument is made by Bolton and Rosenthal (2002). In their model voters would have the political power to enact legislation that protects debtors against creditors when the economy is facing an exceptionally large downturn. Bolton and Rosenthal show that when large, adverse shocks are rare events, political intervention to help debtors improves ex-ante welfare by completing incomplete contracts. Even though Bolton and Rosenthal model debt

currency temporarily, also ask the government's permission to float the currency permanently. 
rescheduling or forgiveness, their analysis could easily be extended to bankruptcy law reforms. In addition, the macroeconomic crisis may disturb the balance of power between interest groups supporting and opposing the reform, which was the case in Finland, as previously powerful labor and banking sectors lost some of their political power due to the crisis.

Since the economic crisis took place in the aftermath of liberalization of capital flows, the events in Finland also fit well the theory advanced by Rajan and Zingales (2003) that predicts that reforms and financial market development occur in an economy that has opened its borders to both trade and capital flows. Whether the Finnish legal reforms in 1991-1993 were caused primarily by economic crisis or liberalization of capital flows is a question beyond the scope of this paper. However, the pace at which the reforms went through the legislative process suggests that the depth of the economic crisis was the major contributing factor in speeding these reforms into laws. 


\section{$7 \quad$ Conclusions}

This paper shows that the major legal reforms in Finland have lead to higher corporate valuations. We study two kinds of legal reforms: those that increase shareholder protection by improving public enforcement of securities market laws and those that weaken creditors' rights by facilitating reorganization of distressed companies. We show that both kinds of reforms lead to positive abnormal returns when the bills are introduced to the parliament, but only the latter reforms lead to more positive abnormal returns for levered firms. We obtain consistent results with panel regressions, where the dependent variable is the Tobin's q: more levered firms experience a higher increase in q. We argue that our evidence supports the notion that properly designed bankruptcy legislation creates wealth rather than merely transfers it.

The typical empirical study into investor protection laws uses cross-sectional data in an attempt to show that good investor protection and high stock prices are positively correlated. In these studies, the causation could go either way: high level if investor protection could indeed lead to high stock valuations, but it could be equally plausible that high stock valuations improve corporate governance, thus leading to good investor protection. Moreover, it is not a priori clear whether strong creditor protection is conducive for financial market development or not. Since we use the event study methodology, and the legal reforms were introduced in the midst of a deep recession when the stock prices were also in doldrums, we are able show that improved shareholder and weakened creditor protection laws indeed lead to higher stock prices and not vice versa. We deem this to be the major contribution of our paper.

Our study also has bearings on the debate about whether public enforcement matters for financial market development. Based on cross-sectional data, the existing research 
suggests that public enforcement does not improve financial market development. Our results contrast this view: we find evidence that the stock market welcomed the introduction of an independent Financial Supervisory Authority. Since the reform also concentrated supervisory resources into a single entity, our finding also supports calls for increased consolidation of supervision of financial institutions across countries and industries.

The legal reforms we study constituted a part of the Finnish government's extensive policy response to the economic and banking crisis. Although we do not providing an overall assessment of the government's crisis resolution effort is beyond the scope of this paper, we think that the legal reforms were among the most successful crisis management policies implemented in Finland. In the midst of a severe economic crisis, making the reorganization of financially distressed companies easier was especially important. As a longer-term measure - so not necessarily from an immediate crisis management perspective - we deem the creation of an independent Financial Supervisory Authority to be very valuable. The creation of the new authority helped to improve the credibility and fairness of equity markets and facilitated the transition from a bank dominated financial system to a more market based system.

The severe economic crisis also sheds light on the politics of corporate governance reforms. The crisis took place in the aftermath of capital market liberalization, which has then been blamed for the crisis. However, Rajan and Zingales (2003) suggest that capital market liberalization in an open economy such as Finland should be conducive for financial market development, since incumbents have little reasons or capabilities to resist reforms. During the crisis bankruptcies reached unprecedented levels and Finnish banks were struggling. The banking crisis implied a deterioration of banks' traditionally strong industrial and political power. They were in a weak position to oppose the substantial worsening of creditor rights which seemed to run against their interests. Moreover, their 
traditional clients, the established industrial firms, were either on the verge of bankruptcy or tapping foreign markets for cheaper finance, and so the banks needed to seek new profit opportunities among new entrepreneurs and younger firms. Since the incumbent financial institutions had no information advantage in new markets, they were gaining from stronger public supervision, and the creation of the new Financial Supervisory Authority was also in their interests.

From the ruins of Finland's previously bank dominated financial system emerged a more equity finance oriented system that has served Finnish companies well. The next logical step would be to examine changes in equity issuance, in particular IPOs, ownership concentrations and dividend policies in Finland before and after the reforms. That is left for a further study. 


\section{References}

Ali, A., and S. Kallapur, 2001, "Security Price Consequences of the Private Securities Litigation Reform Act of 1995 and Related events", Accounting Review 76, 431$\underline{460 .}$

Barth, J. R., Caprio, G. Jr., and Levine, R., 2004, "Bank Regulation and Supervision: What Works Best?", Journal of Financial Intermediation 13, 205-248.

Barth, J. R., Caprio, G. Jr., and Levine, R., 2006, Rethinking Banking Regulation: Till Angels Govern, Cambridge University Press, Cambridge.

Bergström, C., Eisenberg, T., and Sundgren, S., 2004, "On the Design of Efficient Priority Rules for Secured Creditors: Empirical Evidence from A Change in Law", European Journal of Law and Economics 18, 273-297

Binder, J.J., 1985, "Measuring the Effects of Regulation with Stock Price Data", Rand Journal of Economics 16, 167-183.

Bolton, P., and Rosenthal, H., 2002, "Political Intervention in Debt Contracts", Journal of Political Economy 110, 1103-1134.

Bolton, P. and Scharfstein, D., 1996, "Optimal Debt Structure and the Number of Creditors", Journal of Political Economy 104, 1-25.

Brown, S.J., and Warner, J., 1985, "Using Daily Stock Returns: The Case of Event Studies", Journal of Financial Economics 14, 3-31.

Cornelli, F., and Felli, L., 1997, "Ex-Ante Efficiency of Bankruptcy Procedures", European Economic Review 41, 475-485.

Campbell, J.Y., Lo, A.W., and MacKinlay, A.C., 1997, The Econometrics of Financial Markets, Princeton University Press, Princeton, NJ. 
Corsetti, G. and Roubini, N., 1996, "Budget Deficits, Public Sector Solvency and Political Biases in Fiscal Policy: A Case Study of Finland", Finnish Economic Papers, 9, 18-36.

Demirgüç-Kunt, A., and Maksimovic, V., 1998, "Law, Finance, and Firm Growth", Journal of Finance 53, 2107-2137.

Drazen, A., 2000, Political Economy Macroeconomics. Princeton University Press: Princeton, NJ.

Drazen, A., and Easterly, W., 2001, "Does Crisis Induce Reform? Simple empirical Test of Conventional Wisdom", Economics and Politics 13, 129-157.

Easterbrook, F.H., 1990, “Is Corporate Bankruptcy Efficient?”, Journal of Financial Economics 27, 411-418.

Fazzari, S., Hubbard, R.G., and Petersen, B., 1988, "Financing Constraints and Corporate Investment”, Brookings Papers on Economic Activity, 141-95.

Giannetti, M., and Koskinen, Y., 2007, "Investor Protection, Equity Returns, and Financial Globalization", working paper.

Gompers, P., Ishii, J., and Metrick, A., 2003, "Corporate Governance and Equity Prices", Quarterly Journal of Economics 118, 107-155.

Honkapohja, S., and Koskela, E., 1999, "The Economic Crisis of the 1990s in Finland", Economic Policy 29, 401-436.

Honohan, P. and Klingebiel, D., 2003, "The Fiscal Cost Implications of an Accommodating Approach to Banking Crises", Journal of Banking and Finance $\underline{27,1539-1560}$

Hyytinen, A., Kuosa, I., and Takalo, T., 2003, "Law or Finance: Evidence from Finland", European Journal of Law and Economics 16, 59-89.

IMD, World Competitiveness Yearbook 1990, Lausanne.

IMD, World Competitiveness Yearbook 2005, Lausanne. 
Jonung, L., Söderström, H. T. and Stymne, J., 1996, "Depression in the North - Boom and Bust in Sweden and Finland", Finnish Economic Papers, 9, 55-71.

Kang, J.K., and Stulz, R.M., 1997, "Why is There a Home Bias? An Analysis of Foreign Portfolio Equity Ownership in Japan”, Journal of Financial Economics 46, $3-28$

Kane, E.J. and Klingebiel, D., 2004, "Alternatives to Blanket Guarantees for Containing a Systemic Crisis", Journal of Financial Stability 1, 31-63.

Karpoff, J., and P. Malatesta, 1989, "The wealth effects of second-generation state takeover legislation", Journal of Financial Economics 25, 291-322.

La Porta, R., Lopez-de-Silanes, F., and Shleifer, A., 2006, "What Works in Securities Laws?", Journal of Finance 61, 1-32.

La Porta, R., Lopez-de-Silanes, F., Shleifer, A., and Vishny, R., 1997, "Legal Determinants of External Finance", Journal of Finance 52, 1131-1150.

La Porta, R., Lopez-de-Silanes, F., Shleifer, A., and Vishny, R., 1998, "Law and Finance", Journal of Political Economy 106, 1113-55.

La Porta, R., Lopez-de-Silanes, F., Shleifer, A., and Vishny, R., 2000, "Investor Protection and Corporate Governance", Journal of Financial Economics 58, 2-27.

La Porta, R., Lopez-de-Silanes, F., Shleifer, A., and Vishny, R., 2002, "Investor Protection and Corporate Valuation", Journal of Finance 57, 1147-1171.

Lehn, K., Patro, S., and Zhao, M., 2006, "Governance Indices and Valuation: Which Causes Which?”, working paper, University of Pittsburgh.

Levine, R., 2001, "International Financial Liberalization and Economic Growth", Review of International Economics 4, 688-672.

Nyberg, P. and Vihriälä, V., 1994, "The Finnish Banking Crisis and Its Handling", Bank of Finland Discussion Papers 7/94. 
Pagano, M., and Volpin, P., 2005, "The Political Economy of Corporate Governance", American Economic Review 95, 1005-1030.

Pagano, M., and Volpin, P., 2006, "Shareholder Protection, Stock Market Development, and Politics", Journal of the European Economic Association 4, 315-341.

Porter, M. E., Sala-i-Martin, X., Schwab, K., and Lopez-Claros, A. (2004) The World Economic Forum's Global Competitiveness Report 2004-2005. Palgrave: New York, N.Y.

Perotti, E., and von Thadden, E-L., 2006, "The Political Economy of Corporate Control and Labor Rents", Journal of Political Economy 114, 145-173.

Pistor, K., 2000, "Patterns of Legal Change: Shareholder and Creditor Rights in Transition Economies", European Business Organisation Law Review 1, 59-108.

Pistor, K., Raiser, M., and Gelfer, S., 2000, "Law and Finance in Transition Economies". Economics of Transition 8, 325-368.

Ravid, S.A., and Sudgren, S., 1998, "The Comparative Efficiency of Small-Firm Bankruptcies: A Study of the US and Finnish Bankruptcy Codes", Financial Management 27, 28-40.

Rajan, R., and Zingales, L., 2003, "The Great Reversals: The Politics of Financial Development in the Twentieth Century", Journal of Financial Economics 69, 5-50. Rajan, R., and Zingales, L., 2004, "Making Capitalism Work for Everyone”, Journal of Applied Corporate Finance 16, 101-108.

Schwert, W., 1981, "Using Financial Data to Measure Effects of Regulation”, Journal of Law and Economics 24, 121-158.

Scott, J.A., and T.C. Smith, 1986, "The Effect of the Bankruptcy Reform Act of 1978 on Small Business Loan Pricing", Journal of Financial Economics 16, 119-140. 
Shleifer, A., and R.W. Vishny, 1992, "Liquidation Values and Debt Capacity: A Market Equilibrium Approach", Journal of Finance 47, 1343-1366.

Sorge, M., and K. Virolainen, 2006, “A Comparative Analysis of Macro Stress-testing Methodologies with Application to Finland", Journal of Financial Stability 2, 113151.

Suarez, J., and O. Sussman, 2007, "Financial Distress, Bankruptcy Law and the Business Cycle", Annals of Finance 3, 5-35.

Sundgren, S., 1998, "Does a Reorganization Law Improve the Efficiency of the Insolvency Law" The Finnish Experience", European Journal of Law and Economics 6, 177-198.

Vihriälä, V., 1997, Banks and the Finnish Credit Cycle 1986-1995, Bank of Finland Studies, E:7. 


\section{Appendix}

In this appendix we document and justify the changes in the values of five investor protection indices reported in Section 2. Four of the indices deal with creditor rights and one deals with shareholder rights. Since the creditor rights were more heavily shaped by the reforms, we also explain their determinants more in detail than in the main text.

\section{Changes in the creditor rights}

Prior to the reforms of the 1990s, creditor rights in Finland were largely determined by the Liquidation Bankruptcy Code 31/1868 (effective 9 Nov 1868), the Decree on Claim Priorities 32/1868 (effective 9 Nov 1868), the Act on Compositions 148/1932 (effective 10 May 1932), and the Companies Act 734/1978 (effective 1 Jan 1980). The three new creditor right laws introduced in the early 1990s were: the Act on Restitution of Assets in Bankruptcy 758/1991 (effective 1 Jan 1992), the Act on Claim Priorities 1578/1992 (effective 1 Jan 1993), and the Act on Reorganization of Companies 47/1993 (effective 8 Feb 1993). All new laws are relevant for our coding of the indices, although our analysis in the main body of the text focuses on the Act on Reorganization of Companies and the Act on Restitution of Assets in Bankruptcy. As we argue below, only these two laws resulted in changes in the creditor rights index values.

The most well known of the indices we study is the creditor rights index developed by La Porta et al. (1998). It consists of four binary variables, each of which obtains value one if the law includes the provision and zero otherwise. The four variables are i) Restrictions for going into reorganization; ii) No automatic stay on secured assets; iii) Secured creditors ranked first; and iv) Management does not stay in reorganization. All four variables were touched by the reforms as indicated below.

i) Restrictions for going into reorganization. Equals one if the reorganization procedure imposes restrictions, such as creditor's consent to file for reorganization; equals zero if there are no such restrictions.

Our coding: The reforms reduce the variable value from 1 to 0 .

Justification: Before the Act on Reorganization of Companies of 1993, reorganization procedure was unknown in Finland. In theory the closest equivalent was compositions of creditors, regulated by the Act of Compositions of 1932, in which junior unsecured creditors agreed to accept partial payment in full settlement of their claims. An alternative, and in practice much more common route of resolution, was liquidation bankruptcy, governed by the Liquidation Bankruptcy Code of 1868. However, the goal of liquidation is fundamentally different than reorganization and, hence, it is not a proper point of reference here. This view is also shared by the Finnish lawmakers who explicitly made compositions rather than liquidation as the reference point to which the proposed reorganization procedure were assessed (Government bill 182/1992).

The Act of Compositions dictated that compositions procedure could not be started without an approval by a majority of junior creditors. However, the participation of senior secured creditors in compositions was entirely voluntary and required waiving of their priority. Because La Porta et al.'s creditor right index should be coded from the perspective of senior secured creditors, it is clear that the index value is one before the reform. 
The Act on Reorganization of Companies replaced the Act of Compositions. There are some restrictions (6-7§) for going into reorganization: The procedure can be started only if the debtor together with creditors representing at least one fifth of total claims apply for it or if the debtor is either insolvent or threatened by insolvency. Because senior secured debt could not, without permission, be subjected to compositions but could be subjected to reorganization, we judge that the reform reduced the value of this variable from 1 to 0 . Arguably, the index value could perhaps remain one, but it is clear that the reform substantially weakened the senior creditors' control over the initiation of debt rescheduling process. Zero is also the value for Finland reported by La Porta et al. (1998)

ii) No automatic stay on secured assets. Equals one if the reorganization procedure does not impose an automatic stay on the assets of the firm filing for the reorganization petition. Equals zero if such a restriction does exist in the law.

Our coding: The reforms reduce the variable value from 1 to 0 .

Justification: The Act on Reorganization of Companies (17§) states that the debtor is prohibited from paying debt upon entering into reorganization. Only the interest on senior secured debt can be paid (18§). Neither can any collateralized assets be seized to recover the debt $(19 \S, 21 \S)$. These provisions automatically enter in force once reorganization process begins. Prior to the reform, the situation was different, because composition procedure did not concern senior secured debt. While the Act of Compositions imposed restrictions on creditors' ability to recover their debt during a compositions procedure, they did not apply to secured assets. For these reasons, the introduction of the Act of Reorganization of Companies changed the index value from 1 to zero. La Porta et al. (1998) also report the value of Finland to be equal to zero.

iii) Secured creditors first. Equals one if secured creditors are ranked first in the distribution of the proceeds that result form the disposition of the assets of a bankrupt firm. Equals zero if unsecured creditors, such as the government and workers, are given absolute priority.

Our coding: The variable value is 1 and it was unaffected by the reforms.

Justification: While the Act on Reorganization (18§) gave priority to workers' salaries in reorganization, the Act did not affect the priority rankings in liquidation bankruptcy. These priorities were reformed at the same time by the Act on Claim Priorities of 1993, which simplified the complex priority rankings derived from the Decree on Claim Priorities of 1868. The Decree implied that a secured creditor had a "special" priority right to the collateralized asset backing the claim but if the asset was insufficient to recover the full value of the debt, the secured creditor had no priority over other groups holding "general" priority rights such as government and workers. In the reform all numerous general priorities (except for maintenance allowance) were abolished and even maintenance allowance was strictly placed below the collateralized debt in the ranking. The reform did not change the position or rights of senior secured creditors, since they held absolute priority rights to collateralized assets already before the reform. Hence, our view is that the reform did not change the variable value. La Porta et al. (1998) also report the value of one for Finland. However, there is potential for confusion, since La Porta et al. (1998, p.1135) suggest that the variable should 
assess the secured creditors' right to collateral in reorganization rather than in liquidation bankruptcy.

iv) Management does not stay. Equals one when an official appointed by the court, or by the creditors, is responsible for the operation of the business during reorganization. Equivalently, this variable equals one if the debtor does not keep the administration of its property pending the resolution of the reorganization process. Equals zero otherwise.

Our coding: The reforms reduce the variable value from 1 to 0 .

Justification: The purpose of the Act of Reorganization of Companies is to keep the debtor or management in charge of daily business operations of a company and the company's assets during reorganization (29§). There are restrictions on the debtor's and management's authority over the use of a company's property, assets and liabilities in such a way that would hurt creditors interest (29-30§). The Act also requires the courts to appoint an official to monitor the debtor and management to protect creditors' rights $(8 \S)$. Despite the restrictions, however, it is clear that the index value is zero after the reform.

To assess the situation before the establishment of the proper reorganization procedure is difficult. Neither the management nor the debtor was able to control the company's assets during liquidation procedure but remained in control during composition procedure. Above we suggest that the right point of reference is the composition procedure, in which case the right index value would be zero also prior to the reform. However, compositions were rare because main (secured) creditors were unwilling participate in them and preferred liquidation. Moreover, since compositions did not pertain to senior secured debt, which is the base for coding, the reform enabled the debtor or management to control collateralized assets in reorganization. It is thus justifiable to think that the index value was 1 before the introduction of the Act of Reorganization of Companies, and that the introduction changed the value of the variable from 1 to 0. Zero is the value also in La Porta et al. (1998).

v) Legal Reserve. This is the fifth creditor protection variable coded by La Porta et al. (1998). It is given by the minimum percentage of total share capital mandated by corporate law to avoid the dissolution of an existing firm. The value of this variable is continuous and it is not part of their creditor rights index. The variable was beyond the scope of the reforms of the early 1990s, since this provision was included in the Companies Act of 1978 (Ch. 13, 2§).

The other three creditor protection indices we study are developed by Pistor (2000) and Pistor et al. (2000). With respect to these indices, we below focus on the changes in the aggregate index values rather than go though the variables one by one.

LLSVCr index, i.e., the extended La Porta et al. creditor right index, includes all four variables from La Porta et al. and their additional variable, legal reserve, transformed to a discrete form. The legal reserve variable obtains value 0.5 if a simple majority is required and 1 for a qualified majority.

Our coding: The reforms reduce the index value from 4 to 1 .

Justification. We code the value of the discrete legal reserve variable to be zero in the case of Finland, since the legal reserve only amounted to one third of total shares 
(Companies Act 734/1978, Ch. 13, 2§). As mentioned, there was no change in this variable. So this index should take exactly the same values as the basic La Porta et al'.s creditor right index.

CREDCON index, which aims at measuring creditors' control of bankruptcy process, includes five variables. Three variables come from La Porta et al. (variables ii-iv) from above). In addition, there are two new variables: automatic trigger to file for a bankruptcy and creditors' consent required for an adoption of liquidation or a reorganization plan.

Our coding: The reforms reduce the index value from 3 to 1 .

Justification: The implementation of a reorganization plan under the Act on Reorganization of Companies is much easier the implementation of a compositions proposal under the Act on Compositions. However, the reform did not affect the requirements for adopting a liquidation plan.

The question of whether and when one should or could file for a bankruptcy were in turn covered by the Liquidation Bankruptcy Code of 1868 and the Companies Act of 1978, which were also untouched by the reforms. So the change in the index value is entirely driven by the change in the La Porta et al.'s creditor right index variables ii) and iv).

REMEDY index, which measures rules that empower creditors with ex post control rights, consists of three variables: i) Legal provision that allow creditors to pierce the corporate veil; ii) The management can be held viable for violating the provisions of insolvency law (lower threshold than criminal activities required) and iii) transactions preceding the opening of the bankruptcy process can be declared null an void. The two first variables are binary variables but the third variable takes values $0.25,0.5 ., 0.75$ or 1 if transactions up to $3,6,12$ or more than 12 months, respectively, prior to bankruptcy can be annulled.

Our coding: The reforms raised the index value from 1.5 to 2 .

Justification: The Act on Restitution of Assets in Bankruptcy of 1991 changed value of the third variable. Preceding the Act, the Liquidation Bankruptcy Code postulated several time limits concerning revoking transactions that occur prior to the beginning of the bankruptcy process. For example, the transactions could be cancelled up to one year before the launch of bankruptcy process if they were taken by management or other insiders closely tied to the bankrupt company. But the limit was only six months for transactions by others. The reform raised these limits to three and one years, respectively. Therefore we argue that the variable value changed from 0.5 to 1 . One could argue for the value of one already prior to the reform. However, while the issue is debatable before the reform, the conditions for the value of one are clearly satisfied after the reform. Therefore, a chance in this respect is evident.

\section{Changes in shareholder rights}

The reforms of the early 1990 did not affect the shareholder indices developed by La Porta et al. (1998) but they did affect Pistor et al.' s stock market integrity index (SMINTEGR) measuring the protection of market liquidity. It consists of six variables: i) Conflict of interest rules, including rules on disclosing conflict and abstaining from voting are included in the law; ii) Shareholder register must be conducted by an 
independent firm (not by issuing company); iii) Insider trading prohibited by law; iv) Acquisitions of larger blocs of shares triggers mandatory disclosure (threshold); v) A state agency conducts capital market supervision; vi) Capital market supervision is formally independent.

Our coding: The reforms raised the index value from 5 to 6 .

Justification: The Act on Financial Supervision Authority of 1993 changed the sixth variable. Since the year 1989 capital markets were supervised by the Banking Supervision Agency, which operated under the control of the Ministry of Finance. The creation of the FSA made capital market supervision independent from government. The FSA operates in connection with the Bank of Finland and both the FSA and the Bank of Finland are directly overseen by the Parliament. We thus argue that reform upgraded the value of the sixth variable from 0 to 1 . 


\section{Table 1}

\section{Major Events and Legal Reforms During the Finnish Economic Crisis}

August 17, 1990

October 1990

January 1991

January 1991

June 7, 1991

April 26, 1991

The Act on Restitution of Assets in Bankruptcy is introduced to the Parliament

Unemployment starts to grow rapidly.

GDP growth was $0.3 \%$ in 1990 .

The average annual unemployment rate was 3.4\% in 1990. However, unemployment increased by $50 \%$ compared to the previous January.

The Finnish markka is pegged to the European Currency Unit (ECU).

The Act on Restitution of Assets in Bankruptcy is enacted by the Parliament

September 19, 1991 Banking crisis starts. Bank of Finland takes over Skopbank and guarantees all its liabilities.

November 14, 1991 One month interest rate reaches $27 \%$.

November 15, 1991 The Finnish Markka is devalued by 12.3\%, but the currency remains pegged to the ECU.

January 1992 GDP declined by $7.1 \%$ in 1991.

March 18, 1992

April 30, 1992

The Government offers to invest 8 billion markkas in Finnish banks. The Government Guarantee Fund is established in order to avoid bank defaults. During 1992 the Fund invests 20 billion markkas in the banking sector.

September 7, 1992 One month interest rate reaches $20 \%$.

September 8, 1992 The Finnish markka is floated and it depreciates by $11-13 \%$ during September.

September 25, 1992 The Act on Claim Priorities and The Act on Reorganisation of Companies are introduced to the Parliament.

November 27, 1992 The Act on Financial Supervisory Authority is introduced to the Parliament.

December 30, 1993 The Act on Claim Priorities is enacted by the Parliament.

January 1993 GDP declined by 3.6\% in 1992.

January 25, 1993

June 11, 1993

The Act on Reorganisation of Companies is enacted by the Parliament.

October 22, 1993 The Act on Financial Supervisory Authority is enacted by the Parliament.

November 18, 1993 Savings banks are liquidated and their assets are sold off to other banks.

January 1994 Government-owned asset management company acquires those assets from savings banks that couldn't be sold off to other banks.

January 1, 1995 GDP declined by $1.6 \%$ in 1993.

January 1995 Finland becomes a member of the European Union and joins the European Monetary System.

February 9, 1995 GDP grew by $4.5 \%$ in 1994. The two biggest commercial banks announced that they would merge. 
Table 2

Descriptive Statistics

Panel A: Median Values - Full Sample

Number of obs.

1989

1990

1991

1992

1993
61

69

79

83

88
Revenues

1,353

1,126

768

646

593

$\begin{array}{ccc}\text { Assets } & \text { Leverage } & \text { Tobin's q } \\ 1,768 & 0.233 & 1.168 \\ 1,222 & 0.256 & 1.013 \\ 1,010 & 0.303 & 0.981 \\ 732 & 0.299 & 0.984 \\ 778 & 0.240 & 1.168\end{array}$

Panel B: Median Values - Balanced Panel Number of obs.

Revenues

$\begin{array}{lll}1989 & 57 & 1,353 \\ 1990 & 57 & 1,558 \\ 1991 & 57 & 1,558 \\ 1992 & 57 & 1,721 \\ 1993 & 57 & 1,957\end{array}$

Panel C: Industry Distribution - Balanced Panel

Mining

Construction

$\begin{array}{ccc}\text { Assets } & \text { Leverage } & \text { Tobin's q } \\ 1,768 & 0.233 & 1.168 \\ 2,290 & 0.256 & 1.015 \\ 2,197 & 0.288 & 0.985 \\ 1,998 & 0.287 & 0.992 \\ 1,959 & 0.207 & 1.178\end{array}$

Manufacturing

Transportation

Wholesale Trade

Retail Trade

1

3

27

4

4

3

Finance, Insurance and Real Estate $\quad 12$

Services

Panels $A$ and $B$ report sample medians by observation year. Revenues $=$ net sales in FIM millions, assets = total assets in FIM millions, and leverage = long-term debt $/$ total assets. Tobin's q = (total assets - book value of common stock + market capitalization)/total assets. 
Table 3

Analysis of Stock Reactions to Law Change Events

The Act on Restitution of Assets in Bankruptcy of 1991

CAR t-statistic

First announcement

$0.0022 \quad 0.4077$

Introduction to the parliament

0.0044

0.8729

Enactment

0.0014

0.3511

The Act on Claim Priorities of 1993

First announcement

$0.0045 \quad 0.9015$

Introduction to the parliament*

$0.0209^{\star * \star} \quad 3.8111$

Enactment

$-0.0006-0.0928$

The Act on Financial Supervisory Authority of 1993

First announcement

$0.0105^{\star \star *} \quad 3.0356$

Introduction to the parliament

$0.0178^{\star * *}$

Enactment

$-0.0174^{\star *}$

$-2.2293$

The Act on Reorganization of Companies of 1993

First announcement

$-0.0022-0.5364$

Introduction to the parliament*

$0.0209 * \star \star$

3.8111

Enactment

$-0.0018$

$-0.2449$

* these two laws were introduced to the parliament on the same day.

CARs are estimated using equation $R_{p f, t}=\alpha+\beta_{1} R_{m k t t}+\beta_{2} D_{(-2,+1)}+\varepsilon$

The market portfolio is the MSCI World index. The data included in each regression covers days $(-250,-10)$ and $(-2,+1)$, and the dummy variable $D_{(-2,+1)}$ takes on value of 1 during the event window of $(-2,+1)$, zero otherwise. First announcements are identified from Kauppalehti, and the dates of Introduction the parliament and Enactment by the parliament are obtained from the Finnish Parliament. ${ }^{* \star *},{ }^{\star *}$, and * indicate statistical significance at one percent, five percent, and ten percent level, respectively. 
Table 4

Cross-Sectional Analysis of Abnormal Returns

\begin{tabular}{|c|c|c|c|c|}
\hline Law Change & $\begin{array}{c}\text { Bankruptcy } \\
1991\end{array}$ & $\begin{array}{c}\text { Claim Priorities } \\
1993\end{array}$ & $\begin{array}{c}\text { Supervisory Auth. } \\
1993\end{array}$ & $\begin{array}{l}\text { Reorg. } \\
1993\end{array}$ \\
\hline Constant & $\begin{array}{c}-0.0946^{\star \star} \\
(-1.976)\end{array}$ & $\begin{array}{c}-0.0350 \\
(-0.331)\end{array}$ & $\begin{array}{c}-0.0073 \\
(-0.152)\end{array}$ & $\begin{array}{c}-0.0862 \\
(-0.882)\end{array}$ \\
\hline Leverage & $\begin{array}{c}-0.0657 \\
(-1.098)\end{array}$ & $\begin{array}{c}-0.2475^{\star \star \star} \\
(-4.746)\end{array}$ & $\begin{array}{c}0.0232 \\
(0.425)\end{array}$ & $\begin{array}{l}-0.0064 \\
(-0.094)\end{array}$ \\
\hline Foreign listing & $\begin{array}{l}-0.0033 \\
(-0.288)\end{array}$ & $\begin{array}{l}-0.0047 \\
(-0.202)\end{array}$ & $\begin{array}{c}0.0303 * \\
(1.929)\end{array}$ & $\begin{array}{l}-0.0224 \\
(-1.025)\end{array}$ \\
\hline Institution & $\begin{array}{c}0.0063 \\
(0.764)\end{array}$ & $\begin{array}{l}0.0105 \\
(0.477)\end{array}$ & $\begin{array}{l}0.0127 \\
(0.926)\end{array}$ & $\begin{array}{c}-0.0026 \\
(-0.124)\end{array}$ \\
\hline Market to book & $\begin{array}{l}-0.0009 \\
(-0.770)\end{array}$ & $\begin{array}{c}-0.0006 \\
(-0.333)\end{array}$ & $\begin{array}{l}0.0035 \\
(1.001)\end{array}$ & $\begin{array}{l}-0.2844 \\
(-0.976)\end{array}$ \\
\hline Log(assets) & $\begin{array}{c}0.0081^{\star \star} \\
(2.481)\end{array}$ & $\begin{array}{c}0.0079 \\
(1.061)\end{array}$ & $\begin{array}{c}-0.0023 \\
(-0.672)\end{array}$ & $\begin{array}{c}0.0068 \\
(0.976)\end{array}$ \\
\hline Dividend payout & $\begin{array}{l}-0.0004 \\
(-0.519)\end{array}$ & $\begin{array}{c}0.0006 \\
(0.421)\end{array}$ & $\begin{array}{c}0.0031 \\
(0.862)\end{array}$ & $\begin{array}{c}0.0060 \\
(1.174)\end{array}$ \\
\hline First announcement & $\begin{array}{l}-0.0239 \\
(-1.046)\end{array}$ & $\begin{array}{c}-0.0633^{* * *} \\
(-2.515)\end{array}$ & $\begin{array}{c}0.0171 \\
(0.689)\end{array}$ & $\begin{array}{c}0.0438 \\
(1.058)\end{array}$ \\
\hline Intro & $\begin{array}{l}-0.0162 \\
(-0.657)\end{array}$ & $\begin{array}{c}-0.0858^{\star \star} \\
(-2.467)\end{array}$ & $\begin{array}{l}0.0789 * \star \star \\
(3.297)\end{array}$ & $\begin{array}{c}-0.0021 \\
(-0.060)\end{array}$ \\
\hline Leverage x First ann. & $\begin{array}{c}0.1074 \\
(1.273)\end{array}$ & $\begin{array}{c}0.2790 * \star * \\
(3.412)\end{array}$ & $\begin{array}{c}0.0830 \\
(1.239)\end{array}$ & $\begin{array}{c}-0.1760 \\
(-1.474)\end{array}$ \\
\hline Leverage $x$ & & & & \\
\hline Introduction & $\begin{array}{c}0.0559 \\
(0.549)\end{array}$ & $\begin{array}{c}0.3746 \text { (** } \\
(3.083)\end{array}$ & $\begin{array}{c}-0.0177 \\
(-0.278)\end{array}$ & $\begin{array}{c}0.1201 \\
(0.973)\end{array}$ \\
\hline Adj. R-sq & -0.0216 & 0.0717 & 0.1962 & 0.0552 \\
\hline F-test $p$-value & 0.641 & 0.046 & 0.000 & 0.082 \\
\hline $\mathrm{n}$ & 102 & 124 & 127 & 126 \\
\hline \multicolumn{5}{|c|}{$\begin{array}{l}\text { The dependent variable in all specifications is the }(-2,+1) \text { CAR. Each column represents one of the four } \\
\text { law changes considered. Leverage is calculated as total debt divided by total assets, foreign listing }=1 \\
\text { for firms that are listed on an exchange outside Finland, Institution }=1 \text { for lending institutions, Market to } \\
\text { book = market capitalization/book value of equity, Dividend payout = Cash dividends/EBT. Log(assets) is } \\
\text { the natural log of total assets. First announcement and Introduction are dummy variables taking on the } \\
\text { value of one for each type of event, law enactment serves as a control group in each specification. } \\
\text { Leverage } x \text { First ann. and Leverage } x \text { Introduction are interaction variables between the two stated } \\
\text { variables. The t-statistics (in parentheses) are calculated using White (1980) standard errors. }{ }^{* \star *},{ }^{* \star} \text {, and } \\
\text { * indicate statistical significance at one percent, five percent, and ten percent level, respectively. }\end{array}$} \\
\hline
\end{tabular}


Table 5

Panel Estimation Results

\begin{tabular}{|c|c|c|c|c|}
\hline $\begin{array}{l}\text { Dep. var. } \\
\text { Model }\end{array}$ & $\begin{array}{l}\text { Log(Tobin's q) } \\
\text { Fixed eff. }\end{array}$ & $\begin{array}{l}\text { Log(Tobin's q) } \\
\text { Random eff. }\end{array}$ & $\begin{array}{l}\text { Tob vs US } \\
\text { Fixed eff. }\end{array}$ & $\begin{array}{l}\text { Tob vs US } \\
\text { Random eff. }\end{array}$ \\
\hline Constant & & $\begin{array}{c}0.0114 \\
(0.075)\end{array}$ & & $\begin{array}{c}-0.7477 \\
(-1.442)\end{array}$ \\
\hline Leverage & $\begin{array}{c}-0.4806^{\star \star \star} \\
(-3.580)\end{array}$ & $\begin{array}{c}-0.4278^{\star * \star} \\
(-3.381)\end{array}$ & $\begin{array}{c}-1.0160 * \\
(-1.761)\end{array}$ & $\begin{array}{c}-0.8390 \\
(-1.620)\end{array}$ \\
\hline Log (assets) & $\begin{array}{c}-0.0406 \\
(-0.899)\end{array}$ & $\begin{array}{c}0.0139 \\
(1.293)\end{array}$ & $\begin{array}{c}0.2291 \\
(1.146)\end{array}$ & $\begin{array}{c}0.0739 * * \\
(2.009)\end{array}$ \\
\hline Year 91 & $\begin{array}{c}-0.2474^{\star \star \star} \\
(-5.225)\end{array}$ & $\begin{array}{c}-0.2356^{\star \star *} \\
(-5.388)\end{array}$ & $\begin{array}{c}-0.6925^{\star * *} \\
(-4.434)\end{array}$ & $\begin{array}{c}-0.6478^{\star \star \star *} \\
(-3.406)\end{array}$ \\
\hline Year 92 & $\begin{array}{c}-0.2328^{\star \star \star} \\
(-4.959)\end{array}$ & $\begin{array}{c}-0.2151^{\star \star \star} \\
(-5.070)\end{array}$ & $\begin{array}{c}-1.0303^{* \star *} \\
(-5.202)\end{array}$ & $\begin{array}{c}-0.9804^{\star \star *} \\
(-5.319)\end{array}$ \\
\hline Year 93 & $\begin{array}{c}0.0278 \\
(0.564)\end{array}$ & $\begin{array}{c}0.0515 \\
(1.300)\end{array}$ & $\begin{array}{c}-0.9631^{\star \star \star} \\
(-4.106)\end{array}$ & $\begin{array}{c}-0.9704^{* * *} \\
(-5.670)\end{array}$ \\
\hline Year 91 x Lev & $\begin{array}{c}0.4599^{\star \star \star} \\
(3.716)\end{array}$ & $\begin{array}{c}0.4090^{* * \star} \\
(2.979)\end{array}$ & $\begin{array}{c}0.7963^{\star} \\
(1.818)\end{array}$ & $\begin{array}{c}0.6852 \\
(1.148)\end{array}$ \\
\hline Year 92 x Lev & $\begin{array}{c}0.4611^{* * *} \\
(3.830)\end{array}$ & $\begin{array}{c}0.3926^{* \star \star} \\
(2.988)\end{array}$ & $\begin{array}{c}1.4759^{\star \star \star} \\
(2.816)\end{array}$ & $\begin{array}{c}1.4018^{\star *} \\
(2.464)\end{array}$ \\
\hline Year 93 x Lev & $\begin{array}{l}0.1891 \\
(1.506)\end{array}$ & $\begin{array}{c}0.1159 \\
(0.896)\end{array}$ & $\begin{array}{c}1.1584^{\star} \\
(1.744)\end{array}$ & $\begin{array}{c}1.1358^{\star *} \\
(2.043)\end{array}$ \\
\hline Adj. R-sq & 0.7069 & 0.1267 & 0.5670 & 0.1213 \\
\hline Hausman test $p$ & & 0.633 & & 0.0000 \\
\hline
\end{tabular}

Tobin's $q=$ (total assets - book value of equity + market capitalization)/total assets. Tobin Chg. = Tobin's q year $\mathrm{t}$ Tobin's q year $\mathrm{t}-1-1$. Tob vs US = Tobin's q - U.S. median Tobin's $q$ within the firm's two-digit SIC code. Leverage = non-equity liabilities/total assets. Log (assets) $=$ Log (total assets). Year 91 and Year $92=1$ for observations in each year, respectively, zero otherwise. Year $91 \times$ Lev and Year $92 \times$ Lev are interaction variables between the year dummy variables and Leverage. T-statistics (in parentheses) are calculated using heteroscedasticity-consistent standard errors. ${ }^{* \star *}$, **, and * indicate statistical significance at one percent, five percent, and ten percent level, respectively. 
Table 6

Stock Reactions of Sub-Sample Portfolios

The Act on Restitution of Assets in Bankruptcy of 1991

First announcement

Introduction to the parliament

Enactment

The Act on Claim Priorities of 1993

First announcement

Introduction to the parliament*

Enactment

The Act on Financial Supervisory Authority of 1993

First announcement

Introduction to the parliament

Enactment

The Act on Reorganization of Companies of 1993

First announcement

Introduction to the parliament*

\author{
No Financials \\ CAR

$\mathrm{t}$

0.0021

0.0047

0.0011

\begin{tabular}{|l} 
Financials only \\
CAR
\end{tabular}

0.3883

0.8652

0.2679

0.0022

0.0016

0.0005

0.1861

0.2261

0.0734

$\begin{array}{cr}0.0049 & 0.9052 \\ 0.0201^{\star \star \star} & 3.6588 \\ -0.0006 & -0.0921\end{array}$

$0.0113^{\star \star \star}$

0.0180 ***

3.2153

2.8445

$0.0200 * \star *$

$-2.6841$

$-0.0016$

$0.0201^{\star * *}$

$-0.0016$

$-0.0005-0.0663$

$0.0407^{\star * *} \quad 4.1977$

$-0.0073-0.4461$

0.0060

0.0121

1.0351

0.7529

0.0018

0.1024
Enactment

0.0041

$0.0141^{* *}$

0.0043

0.9082

2.1650

0.4726

0.0023

0.5829

$-0.0009$

$-0.0956$

* these two laws were introduced to the parliament on the same day.

CARs are estimated using equation $R_{p f, t}=\alpha+\beta_{1} R_{m k t,}+\beta_{2} D_{(-2,+1)}+\varepsilon$

The market portfolio is the MSCI World index. The data included in each regression covers days $(-250,-10)$ and $(-2,+1)$, and the dummy variable $D_{(-2,+1)}$ takes on value of 1 during the event window of $(-2,+1)$, zero otherwise. First announcements are identified from Kauppalehti, and the dates of Introduction the parliament and Enactment by the parliament are obtained from the Finnish Parliament. $\star \star \star,{ }^{\star \star}$, and * indicate statistical significance at one percent, five percent, and ten percent level, respectively. 
Table 7

Panel Estimation with Non-Export Industry Indicators

\begin{tabular}{|c|c|c|c|c|}
\hline Dep. var. & q) & q) & US & Tob vs US \\
\hline Model & Fixed eff. & Random eff. & Fixed eff. & Random eff. \\
\hline Constant & & $\begin{array}{c}0.0792 \\
(0.525)\end{array}$ & & $\begin{array}{c}-0.6234 \\
(-1.186)\end{array}$ \\
\hline Leverage & $\begin{array}{c}-0.3975^{\star \star \star} \\
(-2.786)\end{array}$ & $\begin{array}{c}-0.3615^{\star \star \star} \\
(-2.820)\end{array}$ & $\begin{array}{c}-0.3340 \\
(-0.499)\end{array}$ & $\begin{array}{c}-0.4947 \\
(-0.940)\end{array}$ \\
\hline Log (assets) & $\begin{array}{c}-0.0688 \\
(-1.503)\end{array}$ & $\begin{array}{c}0.0080 \\
(0.737)\end{array}$ & $\begin{array}{c}0.0367 \\
(0.179)\end{array}$ & $\begin{array}{c}0.0590 \\
(1.579)\end{array}$ \\
\hline Year 91 & $\begin{array}{c}-0.2437^{\star \star \star} \\
(-5.012)\end{array}$ & $\begin{array}{c}-0.2327^{\star \star \star} \\
(-4.850)\end{array}$ & $\begin{array}{c}-0.5595 * \star \star \\
(-2.995)\end{array}$ & $\begin{array}{c}-0.5626^{\star * \star} \\
(-2.678)\end{array}$ \\
\hline Year 92 & $\begin{array}{c}-0.1882^{* * *} \\
(-3.897)\end{array}$ & $\begin{array}{c}-0.1745^{\star * *} \\
(-3.735)\end{array}$ & $\begin{array}{c}-0.8220^{* * *} \\
(-3.860)\end{array}$ & $\begin{array}{c}-0.8558^{\star * *} \\
(-4.205)\end{array}$ \\
\hline Year 93 & $\begin{array}{c}0.1006^{\star} \\
(1.764)\end{array}$ & $\begin{array}{c}0.1248^{\star \star \star} \\
(2.716)\end{array}$ & $\begin{array}{c}-0.4569^{\star} \\
(-1.887)\end{array}$ & $\begin{array}{c}-0.5018^{\star * *} \\
(-2.531)\end{array}$ \\
\hline Year 91 x Lev & $\begin{array}{c}0.4749^{* \star *} \\
(3.694)\end{array}$ & $\begin{array}{c}0.4254^{\star \star \star} \\
(3.017)\end{array}$ & $\begin{array}{c}0.5388 \\
(1.132)\end{array}$ & $\begin{array}{c}0.4620 \\
(0.746)\end{array}$ \\
\hline Year 92 x Lev & $\begin{array}{c}0.4558^{\star \star *} \\
(3.559)\end{array}$ & $\begin{array}{c}0.3951^{* * *} \\
(2.942)\end{array}$ & $\begin{array}{c}1.2007^{\star *} \\
(2.146)\end{array}$ & $\begin{array}{c}1.2441^{\star *} \\
(2.123)\end{array}$ \\
\hline Year 93 x Lev & $\begin{array}{c}0.1119 \\
(0.822)\end{array}$ & $\begin{array}{c}0.0506 \\
(0.380)\end{array}$ & $\begin{array}{c}0.5267 \\
(0.753)\end{array}$ & $\begin{array}{c}0.7042 \\
(1.225)\end{array}$ \\
\hline Year $91 \mathrm{x}$ & & & & \\
\hline $\begin{array}{l}\text { Nonexp } \\
\text { Year } 92 \text { x }\end{array}$ & $\begin{array}{c}-0.0311 \\
(-0.739)\end{array}$ & $\begin{array}{c}-0.0328 \\
(-0.810)\end{array}$ & $\begin{array}{c}-0.2103 \\
(-1.238)\end{array}$ & $\begin{array}{c}-0.1026 \\
(-0.589)\end{array}$ \\
\hline $\begin{array}{l}\text { Nonexp } \\
\text { Year } 93 x\end{array}$ & $\begin{array}{c}-0.1262^{\star \star *} \\
(-2.712)\end{array}$ & $\begin{array}{c}-0.1238^{\star \star \star} \\
(-3.049)\end{array}$ & $\begin{array}{c}-0.4258^{\star *} \\
(-2.048)\end{array}$ & $\begin{array}{c}-0.2868^{*} \\
(-1.657)\end{array}$ \\
\hline Nonexp & $\begin{array}{c}-0.1004^{\star *} \\
(-1.973)\end{array}$ & $\begin{array}{c}-0.1080^{\star * *} \\
(-2.655)\end{array}$ & $\begin{array}{c}-0.7618^{\star \star *} \\
(-2.738)\end{array}$ & $\begin{array}{c}-0.7879 \text { *** } \\
(-4.565)\end{array}$ \\
\hline Adj. R-sq & 0.7197 & 0.1469 & 0.5864 & 0.1390 \\
\hline Jausman test $p$ & & 0.0000 & & 0.9755 \\
\hline
\end{tabular}

Tobin's $q=$ (total assets - book value of equity + market capitalization)/total assets. Tobin Chg. = Tobin's $q$ year $\mathrm{t} /$ Tobin's $\mathrm{q}_{\text {year } \mathrm{t}-1}-1$. Tob vs US $=$ Tobin's $q$ U.S. median Tobin's q within the firm's two-digit SIC code. Leverage = non-equity liabilities/total assets. Log (assets) $=$ Log (total assets). Year 91 and Year $92=1$ for observations in each year, respectively, zero otherwise. Year $91 \times$ Lev and Year $92 \times$ Lev are interaction variables between the year dummy variables and Leverage. Nonexp is a dummy variable that takes on the value of one for firms that are in service, domestic wholesale, or domestic retail industries. T-statistics (in parentheses) are calculated using heteroscedasticity-consistent standard errors. ${ }^{* \star *},{ }^{* *}$, and * indicate statistical significance at one percent, five percent, and ten percent level, respectively. 